\title{
Hyperpigmented melanistic skin lesions of smallmouth bass Micropterus dolomieu from the Chesapeake Bay watershed
}

\author{
Vicki S. Blazer ${ }^{1, *}$, Kelsey T. Young ${ }^{2,4}$, Geoffrey D. Smith ${ }^{3}$, Adam J. Sperry ${ }^{1}$, \\ Luke R. Iwanowicz ${ }^{1}$ \\ ${ }^{1}$ US Geological Survey, National Fish Health Research Laboratory, Leetown Science Center, Kearneysville, WV 25430, USA \\ ${ }^{2}$ Pennsylvania Sea Grant College Program, Pennsylvania State University, Erie, PA 16505, USA \\ ${ }^{3}$ Pennsylvania Fish \& Boat Commission, Division of Fisheries Management, Harrisburg, PA 17106, USA \\ ${ }^{4}$ Present address: Pathology Department, University of Georgia College of Veterinary Medicine, Athens, GA 30602, USA
}

\begin{abstract}
Hyperpigmented melanistic skin lesions (HPMLs) of smallmouth bass Micropterus dolomieu are observed in the Potomac and Susquehanna rivers, Chesapeake Bay watershed, USA. Routine, nonlethal population surveys were conducted at 8 sites on the mainstem Susquehanna River and 9 on the Juniata River, a tributary of the Susquehanna River, between 2012 and 2018, and the prevalence of HPMLs was documented. A total of 4078 smallmouth bass were collected from the mainstem Susquehanna River and 6478 from the Juniata River. Lesions were primarily seen in bass greater than $200 \mathrm{~mm}$, and prevalence in the Susquehanna River (8\%) was higher $(\mathrm{p}<0.001)$ than in the Juniata River $(2 \%)$. As part of ongoing fish health monitoring projects, smallmouth bass were collected at additional sites, primarily tributaries of the Susquehanna $(n=758)$ and Potomac $(n=545)$ rivers between 2013 and 2018. Prevalence in the Susquehanna River $(13 \%)$ was higher $(\mathrm{p}<0.001)$ than the Potomac $(3 \%)$. Microscopically, HPMLs were characterized by an increased number of melanocytes in the epidermis or within the dermis and epidermis. RNAseq analyses of normal and melanistic skin identified 3 unique sequences in HPMLs. Two were unidentified and the third was a viral helicase (E1). Transcript abundance in 16 normal skin samples and 16 HPMLs showed upregulation of genes associated with melanogenesis and cell proliferation in HPMLs. The E1 transcript was detected in 12 of the 16 melanistic areas but in no samples from normal skin. Further research will be necessary to identify the putative new virus and determine its role in melanocyte proliferation.
\end{abstract}

KEY WORDS: Melanistic skin $\cdot$ Smallmouth bass $\cdot$ Histopathology $\cdot$ Transcript abundance

\section{INTRODUCTION}

Smallmouth bass Micropterus dolomieu are an important sportfish in the Chesapeake Bay watershed and elsewhere, generating millions of dollars in revenue each year (Shull \& Pulket 2015). They are also a top predator and can have significant effects on their prey populations and on habitat complexity and trophic structure (Jackson 2002). Population declines in portions of the Susquehanna river watershed associated with disease (coinfections of multiple

*Corresponding author: vblazer@usgs.gov bacteria, myxozoan and trematode parasites, largemouth bass virus) in young-of-year smallmouth bass (Arway \& Smith 2013, Smith et al. 2015, Walsh et al. 2018) and mortality events, visible skin lesions and similar coinfections of adults in the Potomac watershed (Blazer et al. 2010) have raised concern among the fishing public and resource managers. In addition to these mortality events, visible skin lesions, including melanistic lesions, are commonly observed.

Fish, unlike mammals, have a variety of chromatophores, including erythrophores, xanthophores, cyano-

Outside the USA, @ US Government 2020. Open Access under Creative Commons by Attribution Licence. Use, distribution and reproduction are unrestricted. Authors and original publication must be credited. 
phores, leucophores, iridophores and melanophores/ melanocytes. Color changes in fish are either physiological, due to motile responses of chromatophores, or morphological, due to changes in pigment cell morphology and density (Sugimoto 2002). While melanophore and melanocyte have both been used to describe fish chromatophores that synthesize melanin, it has been suggested for consistency that the term melanocyte be used due to the increasing evidence of conserved genetics in melanocyte biology (Schartl et al. 2016).

Melanosis, melanistic areas or hyperpigmentation has most commonly been reported in marine fish species including Pacific rockfish Sebastes spp. (Okihiro et al. 1993), North Sea dab Limanda limanda (Noguera et al. 2013), Hawaiian goldring surgeonfish Ctenochaetus strigosus (Work \& Aeby 2014), axillary seabream Pagellus acarne, coral trout Plectropomus leopardus and wire netting cod Epinephelus quoyanus (Sweet et al. 2012, Ramos et al. 2013, Diggles et al. 2018). However, these skin abnormalities are also observed in freshwater fishes including salmonids (Brocklebank \& Armstrong 1994), brown bullhead Ameiurus nebulosus (Blazer et al. 2007), and black bass species.

Locally known as the 'blotchy bass syndrome', reports of melanistic areas on otherwise normal-appearing smallmouth and largemouth $M$. salmoides bass collected in New York and Pennsylvania emerged in the 1980s (Carlson 1989, Skinner et al. 1994). Although the syndrome, characterized by irregular, black pigmented areas of varying size on the body surface, fins and mouth, has been recognized for many years, the aetiology is currently unknown. Within the Chesapeake Bay watershed there is a public perception of increasing prevalence, but this has not been substantiated. To better understand the prevalence, mechanisms of development and potential risk factors associated with melanistic lesions in smallmouth bass we (1) compared prevalence of hyperplastic melanistic skin lesions (HPMLs) among sites located in the Susquehanna and Potomac River drainages, (2) described the lesions microscopically, and (3) compared gene expression (transcript abundance) between normal and affected skin samples.

\section{MATERIALS AND METHODS}

\subsection{Sites and field collections}

Smallmouth bass were surveyed at 8 sites on the mainstem Susquehanna River and 9 on the Juniata River (Fig. 1, Table 1) between 2012 and 2018 (sam- pling frequency and sample size are included in Table 2) as part of Pennsylvania Fish \& Boat Commission's routine nonlethal population monitoring surveys. The prevalence of gross anomalies, including HPMLs, total fish length in $\mathrm{mm}$ and water temperature were documented. Fish from 75 to $525 \mathrm{~mm}$ total length (TL) were targeted. Additionally, as part of ongoing fish health monitoring projects, smallmouth bass were collected at 22 sites, primarily tributaries of the Susquehanna and Potomac Rivers (Fig. 1, Table 1) between 2013 and 2018. During the fish health monitoring, attempts were made to collect 20 sexually mature adults (ages $2 \mathrm{yr}$ and older; TL $>200 \mathrm{~mm}$ ) from each site during each sampling period by boat, barge or backpack electroshocking. Actual sample size and sampling times are included in Table 3. Fish were euthanized by immersion in Finquel (MS-222, tricaine methanosulfate $350 \mathrm{mg} \mathrm{l}^{-1}$; Argent Labs) following procedures approved by the Leetown Science Center's Institutional Animal Care and Use Committee. Weight $(\mathrm{g})$ and total length $(\mathrm{mm})$ were measured, abnormalities documented and a complete necropsy performed. Sections of melanistic lesions were placed in $10 \%$ Z-fix (Anatech) or PAXgene ${ }^{\circledR}$ fixative (Qiagen) for histological analysis. Small sections (ca. $5 \mathrm{~mm}$ ) of skin, or skin scrapings, from HPMLs and normal skin of a subset of fish from the Susquehanna River were collected and preserved in RNAlater® (Life Technologies). Lag time between euthanasia and tissue fixation was less than $10 \mathrm{~min}$.

\subsection{Histological examination}

A total of 41 pieces of HPMLs and surrounding normal skin, plus normal skin from 6 bass without melanistic areas were collected from 6 sites in 2013-2017. All but 3 were collected during spring sampling events. Preserved skin samples were decalcified in $0.25 \mathrm{M}$ EDTA (ethylenediaminetetraacetic acid disodium salt; Sigma-Aldrich), pH 7.2 for 2-4 d, trimmed into cassettes and routinely processed. Tissues were embedded in paraffin, sectioned at $6 \mu \mathrm{m}$, stained with hematoxylin and eosin (H\&E), and coverslipped. A subset of sections was bleached for melanin pigment removal by placing in $0.20 \%$ aqueous potassium permanganate solution for $45 \mathrm{~min}$ (Luna 1992) and then stained with H\&E to enhance observations of the cellular structure. Some sections were also stained with Masson's Trichrome (American Mastertech Scientific) following manufacturer's protocol to selectively stain collagen, connective tissue and muscle. 

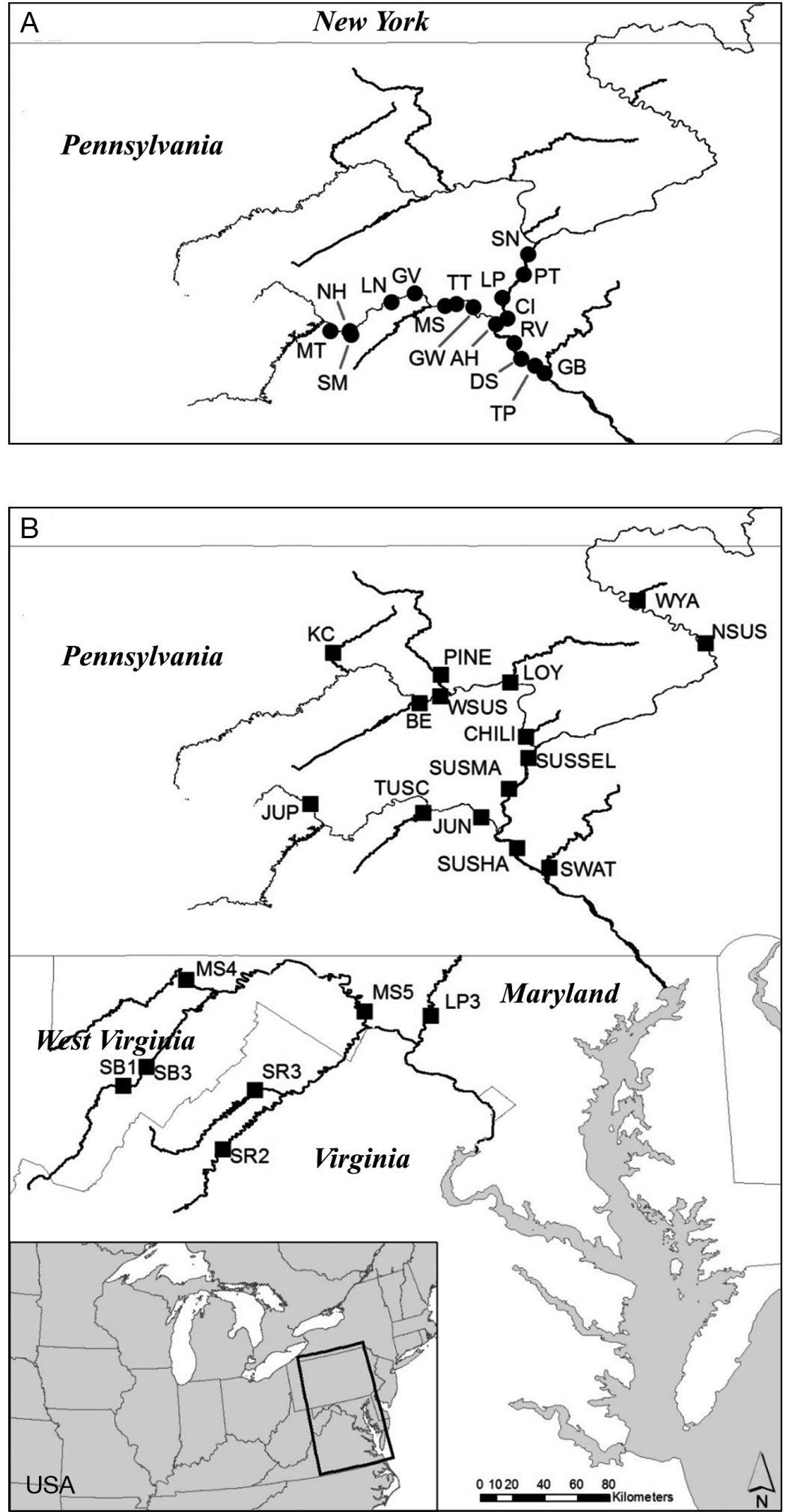

Fig. 1. (A) Sites at which the targeted sampling occurred on the Juniata and mainstem Susquehanna rivers. (B) Fish health assessment site locations within the Susquehanna and Potomac river watersheds. See Table 1 for full site names

\subsection{RNA extractions and sequencing}

Total RNA was extracted using the E.Z.N.A (C) Total RNA Kit I (Omega Bio-tek) following manufacturer's protocol. RNA integrity (RIN) was determined for each sample with the Agilent RNA 6000 Nano Kit on the Agilent 2100 Bioanalzyer (Agilent Technologies). RNA (RIN > 6) from 6 HPMLs and 6 normal skin samples was submitted to the Penn State Genomics Core Facility, University Park, PA, for 2 runs of 150 nucleotide single end read sequencing on an Illumina HiSeq2500 platform (Illumina). Libraries were prepared with the TruSeq Stranded mRNA Library Preparation Kit (Illumina). RNA from additional skin samples $(\mathrm{n}=32$ ) collected in April or November, 2017 , were stored at $-80^{\circ} \mathrm{C}$ for nCounter ${ }^{\circledR}$ (Nanostring Technologies) analysis.

\subsection{Custom CodeSet Nanostring nCounter ${ }^{\circledR}$ analysis assay}

A partial transcriptome was assembled as described in Young (2018). Sequence data is available in BioProject PRJNA530557 (NCBI). Coding regions of genes of interest were identified using Geneious (version R10.1) and verified via BLASTx (Table S1 in the Supplement; www.int-res.com/ articles/suppl/d139p199_supp.pdf). A custom CodeSet was designed by Nanostring Technologies to evaluate transcript abundance of genes associated with melanogenesis, pathogen immune response, and contaminant responses. These probes were selected based on the RNAseq data and the literature. In the annotated set of contigs, only 3 unique sequences were expressed in the HPMLs. Two were unidentified and one was identified as a putative papillomavirus E1 helicase-like gene (GenBank accession no. MT010627). Probes designed to target the E1 gene as well as the major capsid protein of largemouth 
bass virus were included in the CodeSet to target a total of 55 genes (Table 4). Transcript abundance was determined in 16 samples of normal skin and 16 HPMLs (from a total of 27 individual bass) collected in the Susquehanna drainage in 2017. From 4 affected fish a sample of both normal and melanistic skin were compared. Total RNA was quantified using Qubit (Thermo Fisher Scientific), and $50 \mathrm{ng}$ was used in the nCounter® analysis assay conducted per manufacturer protocol.

Quality control of gene expression data was performed with nSolver ${ }^{\mathrm{TM}}$ Analysis Software v4.0. The geometric mean plus 3 standard deviations of the negative control probes were subtracted from each sample to account for background. Normalization of the raw counts was performed using the positive spike controls and housekeeping genes included in the custom CodeSet. Housekeeping genes included TATA box binding protein (TBP), $\beta$-actin ( $\beta A C T), 40$ s ribosomal protein S12 (RPS12) and ribosomal protein L8 (RPL8), which were found to be stable using Normfinder (Andersen et al. 2004).

\subsection{Statistical analysis}

The Bioconductor package NanoStringDiff version 1.16.0 (Wang et al. 2018) was used for differential expression analysis. Raw count data was normalized using the spike-in positive controls, negative controls, and all 5 housekeeping genes from the CodeSet. Differentially expressed genes were determined using the generalized linear model (GLM) likelihood ratio. To reduce type 1 error, p-values were adjusted using the Benjamini and Hochberg method (Benjamini et al. 2006). Genes with an adjusted p-value $<0.05$ were considered differentially expressed. Prevalence data was compared using the chisquare statistic with Yates correction or the Fisher's Exact test (GraphPad Prism version 8.4.1, GraphPad Software).
Table 1. Site descriptions for the surveys (2012-2018) in the Susquehanna drainage, including the Juniata, and the fish health studies (2013-2018) in the Potomac and Susquehanna drainages

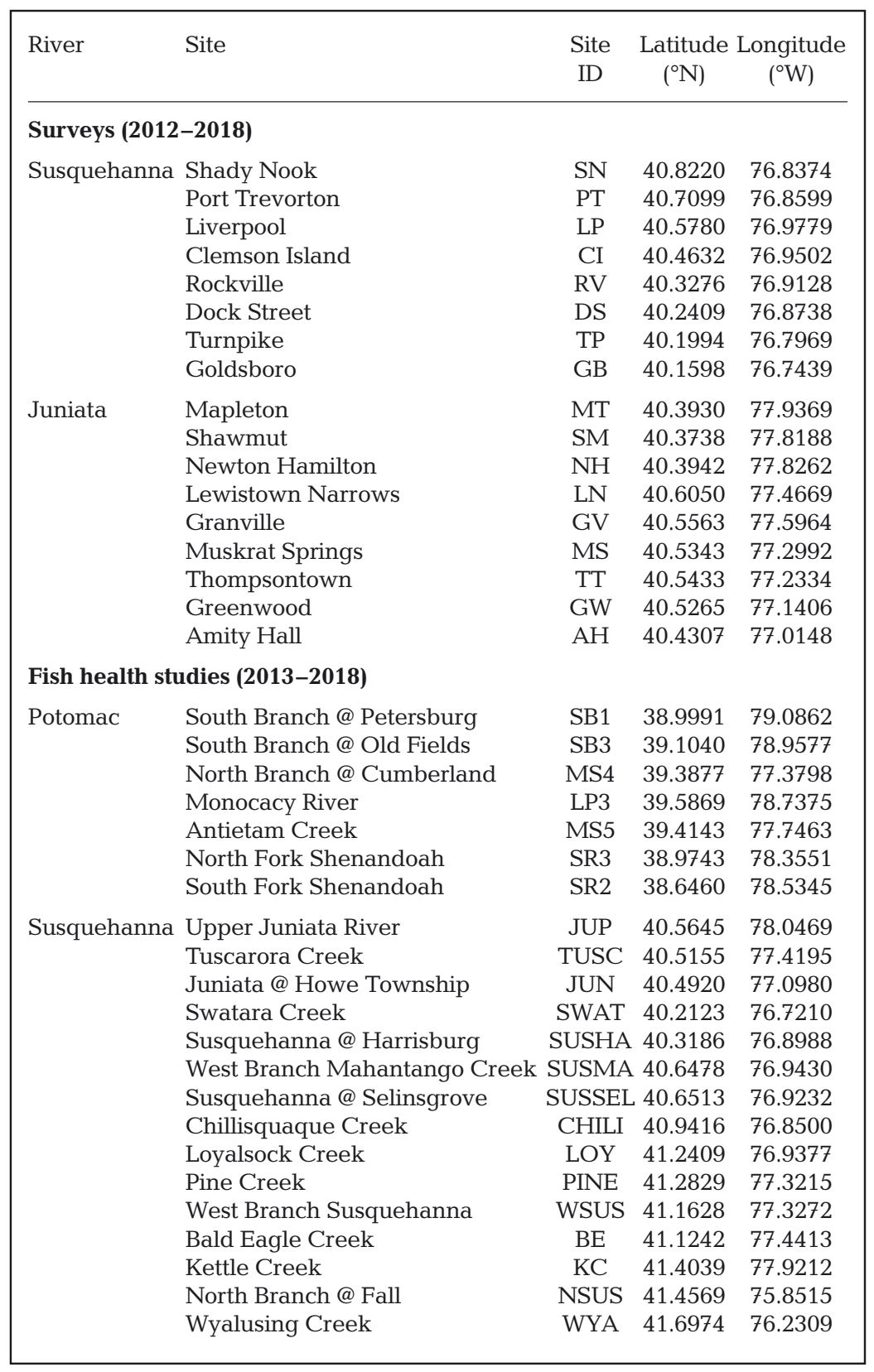

\section{RESULTS}

\subsection{Gross observations}

Melanistic areas were generally irregular, flat areas of black to dark brown pigmentation. Rarely these areas were slightly raised. Size, location and number of areas on an individual fish varied. The lesions ranged from very small $(2-4 \mathrm{~mm})$, round to 
Table 2. Percentage (sample size) of smallmouth bass ( $\geq 200 \mathrm{~mm}$ ) captured in the fall (September through November) with hyperpigmented melanistic lesions. -: no sampling event occurred

\begin{tabular}{|c|c|c|c|c|c|c|}
\hline Site & 2012 & 2013 & 2014 & 2015 & 2016 & 2017 \\
\hline \multicolumn{7}{|c|}{ Susquehanna mainstem } \\
\hline Shady Nook & - & - & 15.7 (191) & $11.0(82)$ & - & $14.1(99)$ \\
\hline Port Trevorton & $15.6(45)$ & - & - & - & - & - \\
\hline Liverpool & $9.7(31)$ & - & - & - & - & - \\
\hline Clemson Island & - & $0.0(73)$ & $7.0(57)$ & $7.0(43)$ & $0.8(118)$ & $1.7(113)$ \\
\hline Rockville & $6.0(50)$ & $14.3(84)^{\mathrm{a}}$ & $14.3(147)^{\mathrm{a}}$ & $10.0(70)^{\mathrm{a}}$ & $6.9(363)^{\mathrm{b}}$ & $2.2(137)^{\mathrm{a}}$ \\
\hline Dock Street & - & $0.0(47)$ & $4.8(62)$ & $0.0(19)$ & $0.0(77)$ & $0.0(17)$ \\
\hline Turnpike & $0.0(6)$ & $0.0(44)^{\mathrm{a}}$ & $20.0(30)$ & $11.4(44)$ & - & $4.4(45)$ \\
\hline Goldsboro & - & $3.5(57)$ & 7.3 (123) & $10.9(55)$ & $6.2(146)$ & $9.7(72)$ \\
\hline All sites & $9.8(132)$ & $4.8(294)$ & $8.9(610)$ & $9.6(313)$ & $5.0(704)$ & $5.8(483)$ \\
\hline \multicolumn{7}{|l|}{ Juniata River } \\
\hline Mapleton & $3.2(31)$ & $0.0(82)$ & $2.6(152)^{a}$ & $3.8(52)$ & $5.0(60)$ & $1.2(81)$ \\
\hline Shawmut & - & - & - & - & - & $3.7(216)$ \\
\hline Newton Hamilton & $1.0(98)$ & $0.0(71)$ & $2.3(130)^{\mathrm{a}}$ & $2.8(108)$ & $4.6(131)$ & $1.4(138)$ \\
\hline Lewistown Narrows & $0.0(113)$ & $0.0(161)$ & $2.5(122)$ & - & $0.0(316)$ & - \\
\hline Granville & - & - & - & - & $2.5(81)$ & $1.3(79)$ \\
\hline Muskrat Springs & $3.7(27)$ & $4.8(21)$ & - & - & - & $0.0(59)$ \\
\hline Thompsontown & $0.0(32)$ & $0.0(14)$ & $0.0(32)$ & $0.0(28)$ & $2.1(140)$ & $0.0(101)$ \\
\hline Greenwood & $0.0(24)$ & $0.0(17)$ & $0.0(32)$ & 7.1 (28) & $0.0(47)$ & $6.1(66)$ \\
\hline Amity Hall & $0.0(49)$ & $5.9(68)$ & - & $3.7(54)$ & $2.5(122)$ & - \\
\hline All sites & $0.8(374)$ & $1.2(418)$ & $2.1(468)$ & $3.3(270)$ & $1.9(897)$ & $2.2(740)$ \\
\hline
\end{tabular}

Table 3. Percentage of smallmouth bass with hyperpigmented melanistic lesions collected at sites within the Susquehanna and Potomac River drainages during fish health studies, 2013-2018. Sample size is 20 unless indicated in parentheses

\begin{tabular}{|c|c|c|c|c|c|c|c|c|c|}
\hline \multirow{2}{*}{ Site } & \multirow{2}{*}{$\begin{array}{c}2013 \\
\text { Spring }\end{array}$} & \multirow{2}{*}{$\begin{array}{c}2014 \\
\text { Spring }\end{array}$} & \multirow{2}{*}{$\begin{array}{c}2015 \\
\text { Spring }\end{array}$} & \multicolumn{2}{|c|}{2016} & \multicolumn{2}{|c|}{-2017} & \multicolumn{2}{|c|}{$2018-$} \\
\hline & & & & Spring & Fall & Spring & Fall & Spring & Fall \\
\hline \multicolumn{10}{|c|}{ Susquehanna River drainage } \\
\hline PINE & - & $0.0(13)$ & $4.3(23)$ & 10.0 & 0.0 & 0.0 & 0.0 & 0.0 & $5.6(10)$ \\
\hline SUSMA & 15.0 & - & 40.0 & 55.0 & 0.0 & 25.0 & 5.0 & 0.0 & 15.0 \\
\hline CHILI & 10.0 & 10.0 & 20.0 & 30.0 & - & 55.0 & - & - & - \\
\hline WYA & 0.0 & - & 5.0 & $7.1(14)$ & - & - & - & - & - \\
\hline JUN & - & 0.0 & 35.0 & - & - & - & - & - & - \\
\hline SUSSEL & 5.0 & - & - & - & - & - & 55.0 & - & - \\
\hline LOY & 20.0 & $6.7(15)$ & - & - & - & - & - & - & - \\
\hline WSUS & - & $0.0(10)$ & 0.0 & - & - & - & - & - & - \\
\hline $\mathrm{BE}$ & - & $0.0(13)$ & 20.0 & - & - & - & - & - & - \\
\hline SUSHA & 35.0 & - & - & - & - & - & - & - & - \\
\hline SWAT & - & $0.0(18)$ & - & - & - & - & - & - & - \\
\hline TUSC & - & 0.0 & - & - & - & - & - & - & - \\
\hline $\mathrm{KC}$ & - & - & $5.9(17)$ & - & - & - & - & - & - \\
\hline NSUS & - & - & $5.9(17)$ & - & - & - & - & - & - \\
\hline JUP & - & - & - & 10.0 & - & - & - & - & - \\
\hline All sites & 14.2 & 2.3 & 15.3 & 23.4 & 0.0 & 26.7 & 20.0 & 0.0 & 10.5 \\
\hline Total samples & $(120)$ & (129) & $(177)$ & $(94)$ & $(40)$ & (60) & (60) & $(40)$ & (38) \\
\hline \multicolumn{10}{|c|}{ Potomac River drainage } \\
\hline SB3 & 10.0 & 0.0 & $7.5 \mathrm{a}(40)$ & 0.0 & - & 0.0 & $7.1(14)$ & 0.0 & 10.0 \\
\hline MS5 & 0.0 & - & 0.0 & 0.0 & 5.0 & 5.0 & - & 0.0 & 10.0 \\
\hline SB1 & 5.0 & - & - & - & - & - & - & - & - \\
\hline MS4 & 0.0 & - & - & - & - & - & - & - & - \\
\hline LP3 & 0.0 & 0.0 & - & - & - & - & - & - & - \\
\hline SR3 & - & 0.0 & - & 0.0 & - & - & - & - & - \\
\hline SR2 & - & 0.0 & - & 0.0 & - & - & - & - & - \\
\hline All sites & 2.1 & 0.0 & 3.8 & 0.0 & 5.0 & 2.5 & 7.1 & 0.0 & 10.0 \\
\hline Total samples & $(140)$ & (93) & $(80)$ & $(78)$ & $(20)$ & $(40)$ & (14) & $(40)$ & $(40)$ \\
\hline
\end{tabular}


Table 4. Gene transcripts included in the Nanostring nCounter codeset for transcript abundance

\begin{tabular}{|c|c|}
\hline Designation & Gene \\
\hline \multicolumn{2}{|c|}{ Pathogen-related genes } \\
\hline E1 & Papillomavirus helicase \\
\hline LMBV MCP & Largemouth bass virus major capsid protein \\
\hline \multicolumn{2}{|c|}{ Melanogenesis/melanocyte-related genes } \\
\hline DCT & L-dopachrome tautomerase \\
\hline PMEL & Melanocyte protein PMEL-like \\
\hline TYR & Tyrosinase \\
\hline TYRP1 & Tyrosinase-related protein $1 \mathrm{a}$ \\
\hline POMC & Pro-opiomelanocortin \\
\hline MC1R & Melanocortin receptor 1 \\
\hline $\mathrm{MC} 2 \mathrm{R}$ & Melanocortin-2 receptor \\
\hline MC5R & Melanocortin receptor 5 \\
\hline KILG & Kit ligand \\
\hline KITA & Mast/stem cell growth factor receptor kita \\
\hline MITF & Micropthalmia-associated transcription factor \\
\hline Rab38 & Ras-related protein Rab-38 \\
\hline \multicolumn{2}{|c|}{ Endocrine-related genes } \\
\hline ARA & Androgen receptor alpha \\
\hline ARB & Androgen receptor beta \\
\hline GR & Glucocorticoid receptor \\
\hline GPER & G couple estrogen receptor \\
\hline THRB & Thyroid hormone receptor beta \\
\hline \multicolumn{2}{|c|}{ Contaminant-related genes } \\
\hline MT1 & Metallothionein \\
\hline CAT & Catalase \\
\hline GST & Glutathione S-transferase theta-1 \\
\hline SOD & Superoxide dismutase \\
\hline CYP1A & Cytochrome P450, family 1 \\
\hline CYP2 & Cytochrome P450, family 2 \\
\hline CYP3A & Cytochrome P450, family 3 \\
\hline ARG1 & Arginase \\
\hline HSP70 & Heat shock protein 70 \\
\hline HSP71 & Heat shock protein 71 \\
\hline HSP90B & Heat shock protein $90 \mathrm{~b}$ \\
\hline \multicolumn{2}{|c|}{ Immune/inflammatory-related genes } \\
\hline CCL4 & C-C motif chemokine 4-like (MIP-b) (CCL4) \\
\hline CXCL11 & C-X-C motif chemokine 11-like (I-TAC) (CXCL11) \\
\hline CD2 & T-cell surface antigen CD2 (CD2) \\
\hline CD4 & T-helper cell glycoprotein (CD4) \\
\hline EPXL & Eosinophil peroxidase-like (EPXL) \\
\hline HLAA & MHC class I antigen (HLAA) \\
\hline IFNAR1 & Interferon alpha/beta receptor 1(IFNAR1) \\
\hline IL12A & Interleukin-12 (IL12A) \\
\hline IL17 & Interleukin-17 (IL17) \\
\hline IL1b & Interleukin-1 beta (IL1b) \\
\hline IL6 & Interleukin-6 (IL6) \\
\hline TNF & Tumor necrosis factor alpha (TNF) \\
\hline CD8A & CD8 alpha chain (CD8A) \\
\hline TLR3 & Toll-like receptor 3(TLR3) \\
\hline TGFB & Transforming growth factor b (tgfb) \\
\hline AKT1 & RAC-alpha serine threonine-kinase \\
\hline \multicolumn{2}{|c|}{ Oncogenes/tumor suppressor genes } \\
\hline BCL-2 & B-cell lymphoma 2 \\
\hline ТР53ВP1 & Apoptosis-stimulating of p53 protein 1-like isoform X1 \\
\hline MAPK1 & Mitogen-activated kinase 1 \\
\hline BRAF & Serine/threonine-protein kinase B-raf \\
\hline RERG & Ras-related and estrogen-regulated growth-related inhibitor \\
\hline \multicolumn{2}{|l|}{ Other } \\
\hline KRT8 & Keratin type II cytoskeletal 8-like \\
\hline CASP3 & Caspase 3 \\
\hline EGFR & Epidermal growth factor receptor \\
\hline TRIM16L & Tripartite motif-containing protein 16 -like \\
\hline WNT11 & Protein Wnt-11 \\
\hline
\end{tabular}

irregular areas on fins and body surface (Fig. 2A) to irregular areas covering much of the body surface (Fig. 2B). In some fish these hyperpigmented areas were noted on the lips (Fig. 2C) and mouth. Two of the bass had areas of depigmentation along the periphery of the melanistic area (Fig. 2D). Commonly, scrapings of the melanistic areas on the body surface resulted in removal of the black tissue which was primarily present in the epidermis covering the scales (Fig. 2E).

\subsection{Spatial and temporal prevalence}

A total of 4078 smallmouth bass ranging in length from 75 to $525 \mathrm{~mm}$ collected from the Susquehanna River between Harrisburg and Selinsgrove were assessed for melanistic lesions between 2012 and 2017 (Table 2). Melanistic areas were observed on $5 \%$ of the fish and were only observed on bass $175 \mathrm{~mm}$ TL or longer. A total of 6478 bass from the Juniata River between Newport and Mapleton were assessed, and $1 \%$ of the fish had melanistic areas. In this watershed melanistic areas were observed on bass $125 \mathrm{~mm}$ and longer. Bass collected in the population monitoring surveys accounted for a broader range of lengths than those collected for fish health assessments. As such, fish under $200 \mathrm{~mm}$ TL were removed from further analysis at all sites. Only 8 fish, 4 from each drainage, with HPMLs fell within these smaller size categories. Prevalence in fish greater than $200 \mathrm{~mm}$ TL was $8 \%$ in the Susquehanna River, which was higher ( $p<0.001)$ than the $2 \%$ observed in the Juniata River (Table 2).

At the Rockville site, sampling events took place in 2 consecutive months (September/October; October/ November) each year from 2013-2017. In 2013 the prevalence of bass with melanistic areas was significantly higher $(p=0.001)$ in October vs. September and in 2016 the prevalence 

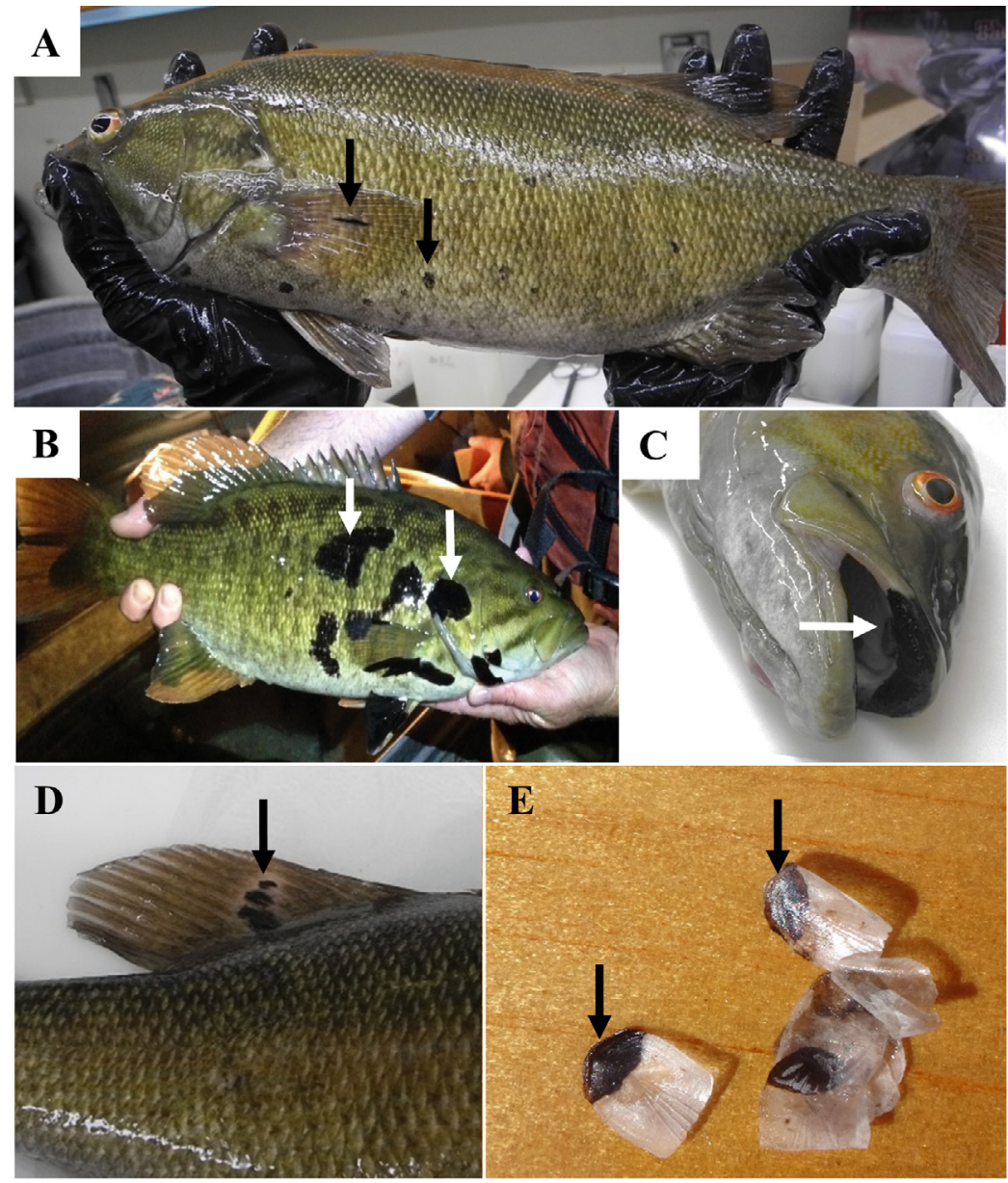

E

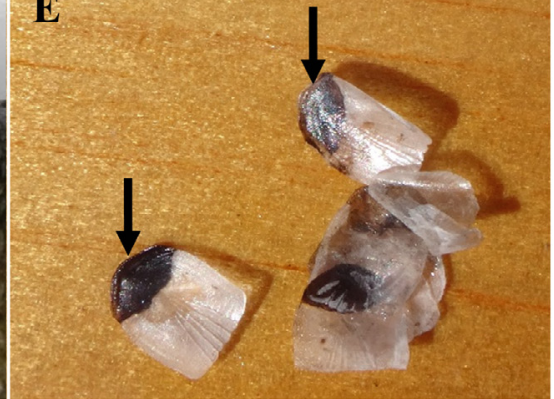

Fig. 2. Visible melanistic areas on smallmouth bass. (A) Small round to irregular black areas on the body surface and fins (arrows). (B) Multiple irregular black areas on the lateral body surface and opercle (arrows). (C) Melanistic area on the upper lip (arrow). (D) Melanistic area on the fin surrounded by a depigmented, pale border (arrow). (E) Scales scraped from a melanistic area on the body surface illustrating the black epidermis (arrows) tial variation in the occurrence of HPMLs was noted with no apparent pattern (Table 3).

\subsection{Histopathology}

Normal skin of smallmouth bass varied in thickness and number of mucous cells in the epidermis, thickness of the dermis and hypodermis depending on body location, season and site. Distinct layers of the epidermis were observed with columnar epidermal cells in the basal region, cuboidal cells in the intermediary region and squamous cells on the surface (Fig. 4A). Normal epidermis contained mucous cells but rarely melanocytes. Epidermis and dermis were separated by a basement membrane of collagen (Fig. 4B). Immediately below this membrane was a layer of melanocytes, loose connective tissue and the scale pocket within the dermis (Fig. 4).

The microscopic appearance of HPMLs varied among individual fish and among individual HPMLs on the same fish. Small melanistic areas were characterized by accumulations of small, compact melanocytes in the epidermis. This was rarely accompanied by a loss of melanocytes at the epidermal/dermal boundary, hemorrhage and inflammation (Fig. 5A). was higher $(\mathrm{p}=0.0014)$ in November vs. October. While the prevalence was elevated in October vs. September of 2014 ( $p=0.1293$ ) and 2015 (0.0960), it was not significantly different. In 2016 the prevalence was higher $(p=0.0014)$ in November than October. In 2017, there was no difference $(p=0.4627)$ between September and October (Fig. 3A). The higher number of bass with HPML was associated with lower temperatures, except in 2017 (Fig. 3B).

In total, 1303 smallmouth bass from 22 sites were collected for fish health assessment studies (Table 3). In the Susquehanna River, 758 smallmouth bass were collected at 15 sites of which $13 \%$ exhibited HPMLs. In the Potomac River, 545 smallmouth bass were collected at 7 sites and $3 \%$ had HPMLs, which was lower $(p<0.001)$ than the prevalence noted in the Susquehanna River. Both temporal and spa-
The epidermis was generally not thickened compared to adjacent normal epidermis, and the transition between normal and melanistic skin was evident with melanocytes present in the epidermis (Fig. 5B). Epidermal melanocytes within the larger HPMLs contained pleomorphic cells of varying size. Large round melanocytes, with dense melanin granules around the periphery of the cell, as well as smaller, stellate melanocytes, were present in the epidermis. In some HPMLs a layer of melanocytes was present in the dermis (Fig. 5C), while in other lesions this layer was not evident (Fig. 5D). Cystic spaces containing numerous melanocytes and cells interpreted as epithelial cells were observed (Fig. 5E). Occasionally, HPMLs contained fewer melanocytes in the epidermis and increased numbers in the dermis (Fig. 5F). Inflammatory cells including eosinophilic 

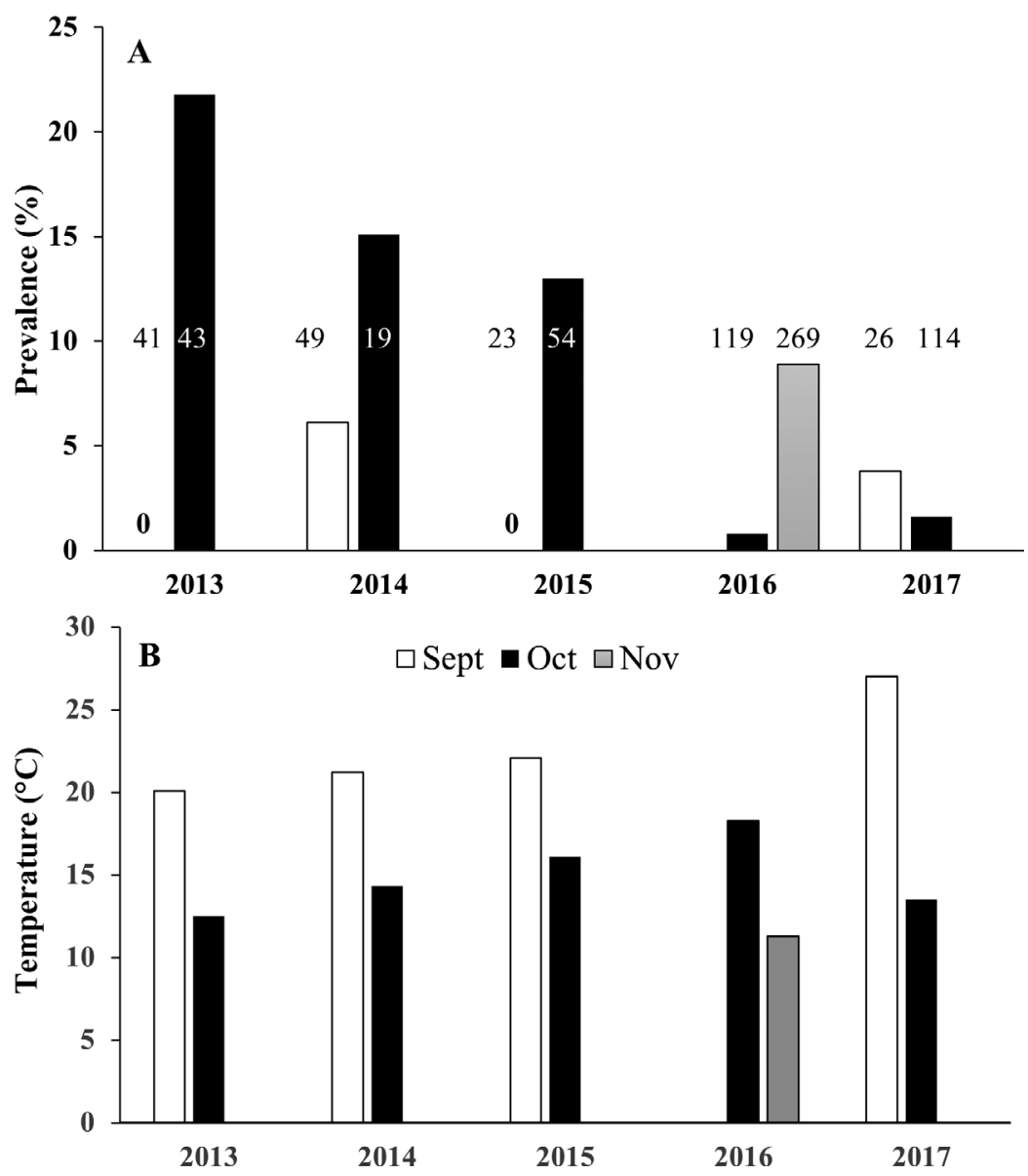

Fig. 3. Melanistic lesion prevalence and temperature observations at the Rockville site. (A) Prevalence between months in years 2013 through 2017. Values above or in the bars are sample sizes, 0 indicates no melanistic lesions observed. (B) Surface water temperature $\left({ }^{\circ} \mathrm{C}\right)$ at the time of collection granular cells and lymphocytes were evident in some lesions (Fig. 5E,F). No obvious inclusion bodies were observed in epithelial cells or melanocytes.

\subsection{Transcript abundance}

Of the 55 genes chosen for transcript abundance using the Nanostring nCounter custom codeset, 11 genes were differentially expressed between HPMLs and normal skin samples collected in 2017 (Table 5). Upregulated genes in the melanistic areas included L-dopachrome tautomerase (DCT), melanocortin receptor 5 (MC5R), micropthalmia-associated transcription factor (MITF), melanocyte protein PMEL-like (PMEL), tyrosinase (TYR), tyrosinase-related protein 1 (TYRP1) and Ras-related protein Rab-38 (Rab38), which are associated with melanogenesis. Additionally, RAC-alpha serine threonine-kinase (Akt1), a kinase which regulates many processes including proliferation, cell survival, growth and angiogenesis, was found to be significantly upregulated in melanistic areas. Two genes, CXC chemokine 11-like and the Wnt 11 protein (WNT11) were downregu-

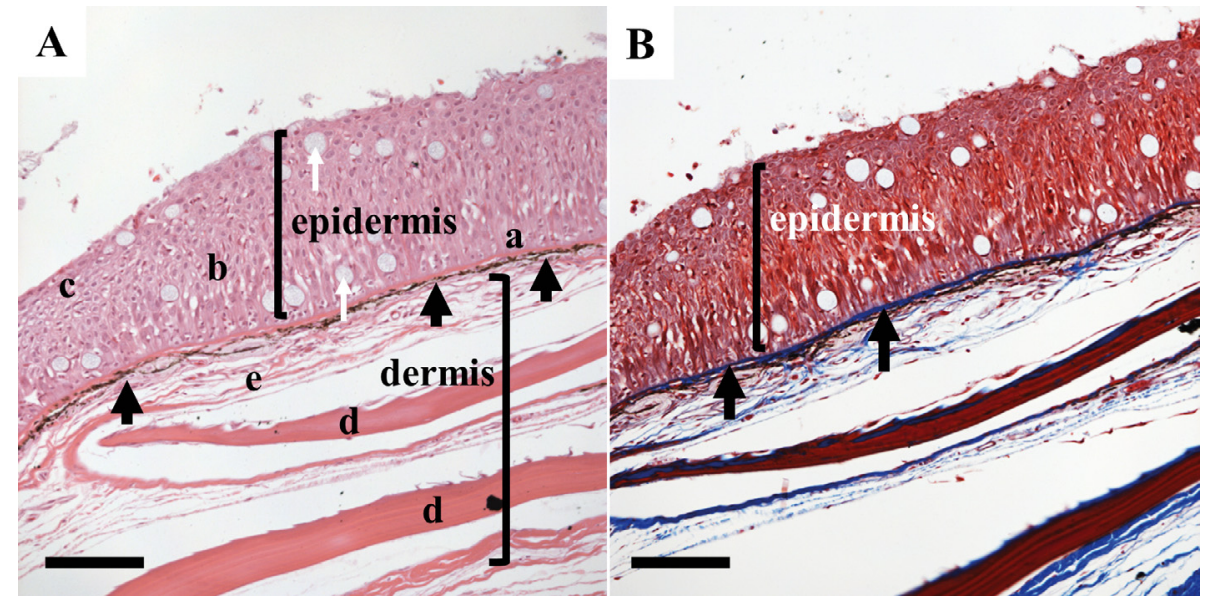

Fig. 4. Microscopic appearance of normal smallmouth bass skin. (A) Epidermis, between upper brackets, illustrating basal columnar epidermal cells (a), cuboidal cells in the intermediate portion (b) and squamous cells on the surface (c). Mucous cells (white arrows) are present in the epidermis. Below the basement membrane of the epidermis is a layer of melanocytes (black arrows). The dermis (between lower bracket) contains the scales (d) and loose connective tissue (e). H\&E stain. Scale bar $=50$ um. (B) Epidermis containing mucous cells (clear cells) and collagen (blue) of the basement membrane (arrows) between epidermis and dermis. Masson's trichrome stain. Scale bar $=50 \mu \mathrm{m}$ 


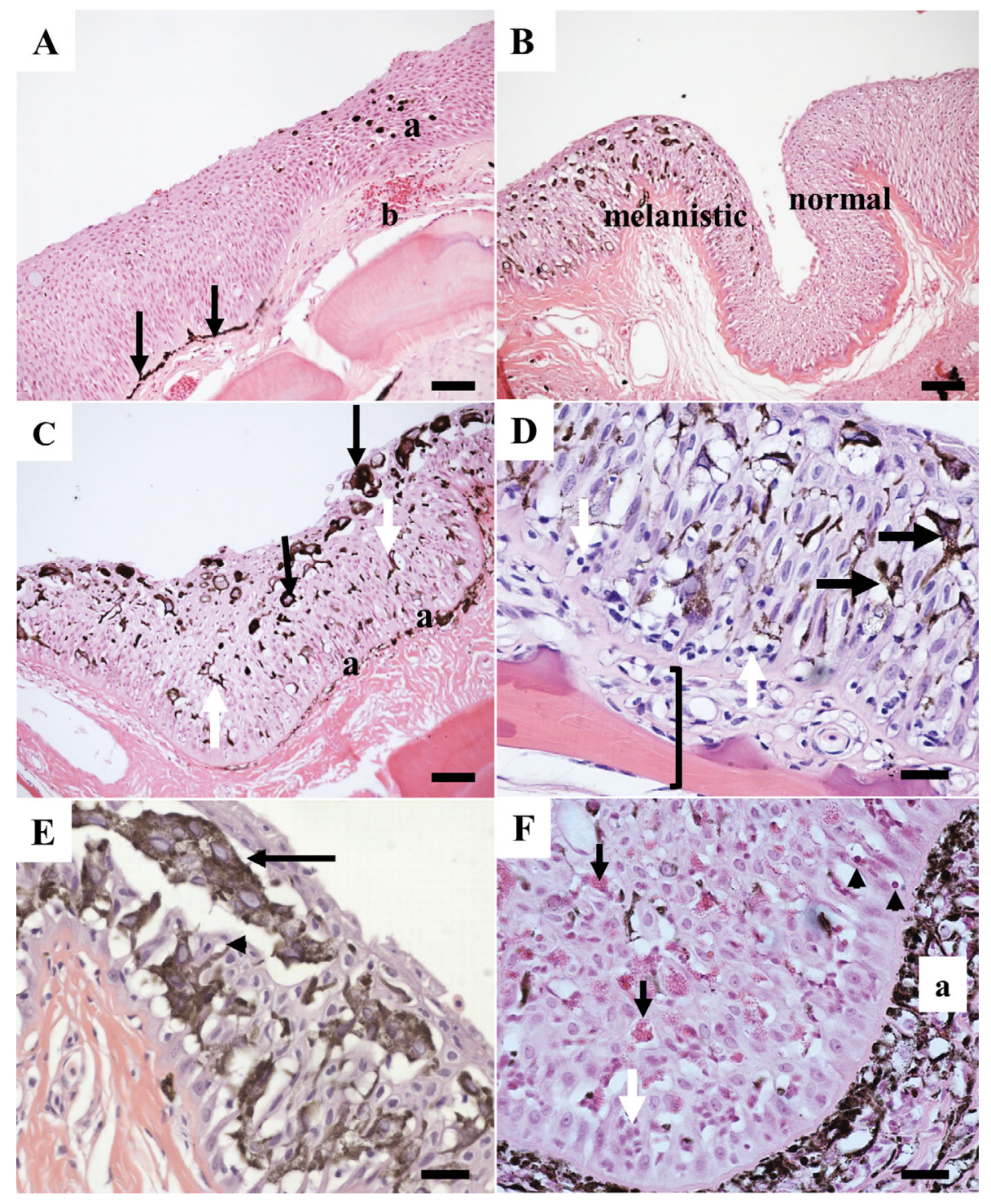

Fig. 5. Microscopic appearance of hyperpigmented melanistic lesions of smallmouth bass. (A) Section from a small melanistic area (as shown in Fig. 2A). A focus of melanocytes (a) within the epidermis, with an area of hemorrhage (b) immediately below within the dermis which is devoid of melanocytes. A layer of melanocytes (arrows) is present below normal epidermis (arrows). Scale bar $=50 \mu \mathrm{m}$. (B) Transition between melanistic and normal areas of skin. Pleomorphic melanocytes are present throughout the epidermis of the melanistic area. Scale bar $=50 \mu \mathrm{m}$. (C) Melanistic skin section containing large, rounded cells with an accumulation of melanosomes in the cytoplasm (black arrows) and more pleomorphic, dendritic melanocytes (white arrows). A layer of melanocytes (a) is evident along the basement membrane of the epidermis. Scale bar $=50 \mu \mathrm{m}$. (D) Melanistic area with numerous dendritic cells (black arrows) and lymphocytes (white arrows) within the epidermis. Dermis (brackets) is devoid of melanocytes. Scale bar $=20 \mu \mathrm{m}$. (E) Melanistic area with cystic spaces containing melanocytes and possibly epidermal cells (black arrow) and numerous dendritic melanocytes, some (arrowhead) appearing to surround epidermal cells. Scale bar $=20 \mu \mathrm{m}$. (F) Melanistic area with an increased number of melanocytes within the dermis (a) and eosinophilic granular cells (black arrows), pyknotic or apoptotic nuclei (arrowheads) and lymphocytes (white arrow) within the epidermis. Scale bar $=20 \mu \mathrm{m}$

lated in melanistic lesions. The viral helicase E1 transcript was detected in 12 of the 16 melanistic areas. No samples from normal skin had detectable levels of this viral transcript (Table 5).

Transcript abundance was measured in HPMLs and normal skin from 4 individual bass. In one indi- vidual none of the 11 genes were significantly different between normal and HPML samples, which may indicate insufficient melanistic skin was included in the sample. In the other 3 individuals there were differences between the 2 sections of skin. Fish 1 was collected in the West Branch Mahantango Creek, a 
Table 5. Transcript abundance (median and range) of differentially expressed genes in 16 normal skin and 16 hyperpigmented melanistic areas of smallmouth bass collected in the Susquehanna River drainage in 2017 and difference between normal and melanistic skin. BD: below detection

\begin{tabular}{|c|c|c|c|c|c|}
\hline \multirow{2}{*}{ Gene } & \multicolumn{2}{|c|}{ — Normal skin —— } & \multicolumn{2}{|c|}{ - Melanistic areas - } & \multirow{2}{*}{ Significance } \\
\hline & Median & Range & Median & Range & \\
\hline E1 & BD & BD-BD & 98.6 & BD-644 & 0.0002 \\
\hline PMEL & 40.4 & $20-162$ & 722.8 & BD-2162 & $<0.0001$ \\
\hline TYR & 15.8 & BD-109 & 283.2 & BD-1079 & $<0.0001$ \\
\hline TYRP1 & 10.9 & BD-52 & 101.1 & BD-782 & 0.0011 \\
\hline DCT & 17.3 & BD-49 & 283.1 & BD-1240 & $<0.0001$ \\
\hline MC5R & 27.3 & $16.1-94$ & 102.4 & BD-328 & 0.0011 \\
\hline AKT1 & 362.8 & $257-501$ & 434.4 & $302-603$ & 0.0075 \\
\hline MITF & 47.9 & BD-91 & 139.6 & $36-510$ & $<0.0001$ \\
\hline Rab38 & 22.1 & BD-78 & 64.3 & BD-272 & 0.0096 \\
\hline WNT11 & 23.2 & BD-123 & BD & BD-BD & 0.0387 \\
\hline CXCL11 & 474.0 & $28-356$ & 92.2 & BD-461 & $<0.0001$ \\
\hline
\end{tabular}

tributary, while Fish 2 and 3 were collected in the mainstem Susquehanna River. Fish 1 was collected in the spring while Fish 2 and 3 were collected in the Fall. In all 3 the E1 transcripts were below detection in normal skin and detectable in HPMLs. In addition, TYR and MITF transcripts were also upregulated in all HPMLs compared to normal skin. Transcripts of PMEL, DCT, TYR and TYRP1 were upregulated in Fish 2 and 3. It is currently not known if this is site or season-related or related to stage of infection (Fig. 6).

\section{DISCUSSION}

External abnormalities of fishes are used worldwide as indicators of environmental health (Baumann 1992, Sanders et al. 1999, Stentiford et al. 2009, Vethaak et al. 2009). Pigment cell hyperplasia and neoplasia in wild fishes have been associated with environmental factors such as UV radiation (Sweet et al. 2012), X-rays (Smith 1932) and chemical contaminants (Kimura et al. 1984, Kinae et al. 1990, Okihiro et al. 1993), although in most wild fish reports no definitive causes have been identified. Hyperpigmentation in North Sea dab, an important sentinel species for assessing contaminant effects, is first noted in 2 or 3 yr old dab (similar to smallmouth bass observations), depending on the site (Stentiford et al. 2010, Grütjen et al. 2013). The higher prevalence noted in older individuals was suggested to indicate a complex etiology (Noguera et al. 2013). The microscopic appearance of dab lesions, characterized by hyperplasia of iridophores, architectural distortion, lymphocyte infiltration and melanosome dispersion into dendritic extensions of melanocytes in the dermal layer, was different than smallmouth bass HPMLs.
In some dab lesions, clusters of melanin-containing cells were observed in the epidermis (Noguera et al. 2013). The prevalence of the dab lesions varied spatially and in certain areas of the North Sea increased from $5 \%$ to $>40 \%$ between 1988 and 2009 (Grütjen et al. 2013). While the prevalence of a number of other fish health indicators (liver tumors, lymphocystis) has declined, providing evidence for a generally improving habitat, the prevalence of hyperpigmentation has continued to increase in most areas of the North Sea (Lang et al. 2017).

Microscopically, HPMLs of smallmouth bass were primarily characterized by increased accumulation of melanocytes in the epidermis and less commonly at the epidermal-dermal interface. The size, number, and shape of melanocytes varied in individual fish. Melanocytes with dendritic extensions were observed in the epidermis of the HPMLs. Some areas were accompanied by infiltration of varying degrees of inflammatory cells (eosinophilic granular cells, lymphocytes) and epidermal hyperplasia. These differences in microscopic appearance may indicate a progression in development of melanotic hyperpigmentation. It is unclear from the current study whether melanocyte hyperplasia in the dermal-epidermal interface occurs prior to migration into the epidermis. In some sections it appeared that as melanocytes migrated to the epidermis, these cells were absent from the dermis, while in other sections there were melanocytes in both dermis and epidermis (Fig. 5).

Based on reports in other species, we hypothesized the HPMLs of smallmouth bass may be related to environmental factors and used the transcript abundance to provide molecular insights into potential causes and mechanisms of development. Red seabream were shown to have increased size and abundance of melanocytes in the epidermis after UV exposure compared to shaded seabream (Adachi et al. 2005). Melanin is a biopolymer with many physiological properties that function to protect the cell. The pigment molecules are free radical scavengers that protect against reactive oxygen species (ROS) which can occur from UV radiation or chemical substances (Otreba et al. 2014). Other molecular defenses against ROS include the upregulation of heat shock proteins (HSP70, HSP 71, and HSP90B), superoxide dismutase (SOD), glutathione-S-transferase (GST), glucocorticoid receptor (GR), and catalase (CAT) (Rodriguez-Ariza et al. 1993, Lushchak 2011). None of 

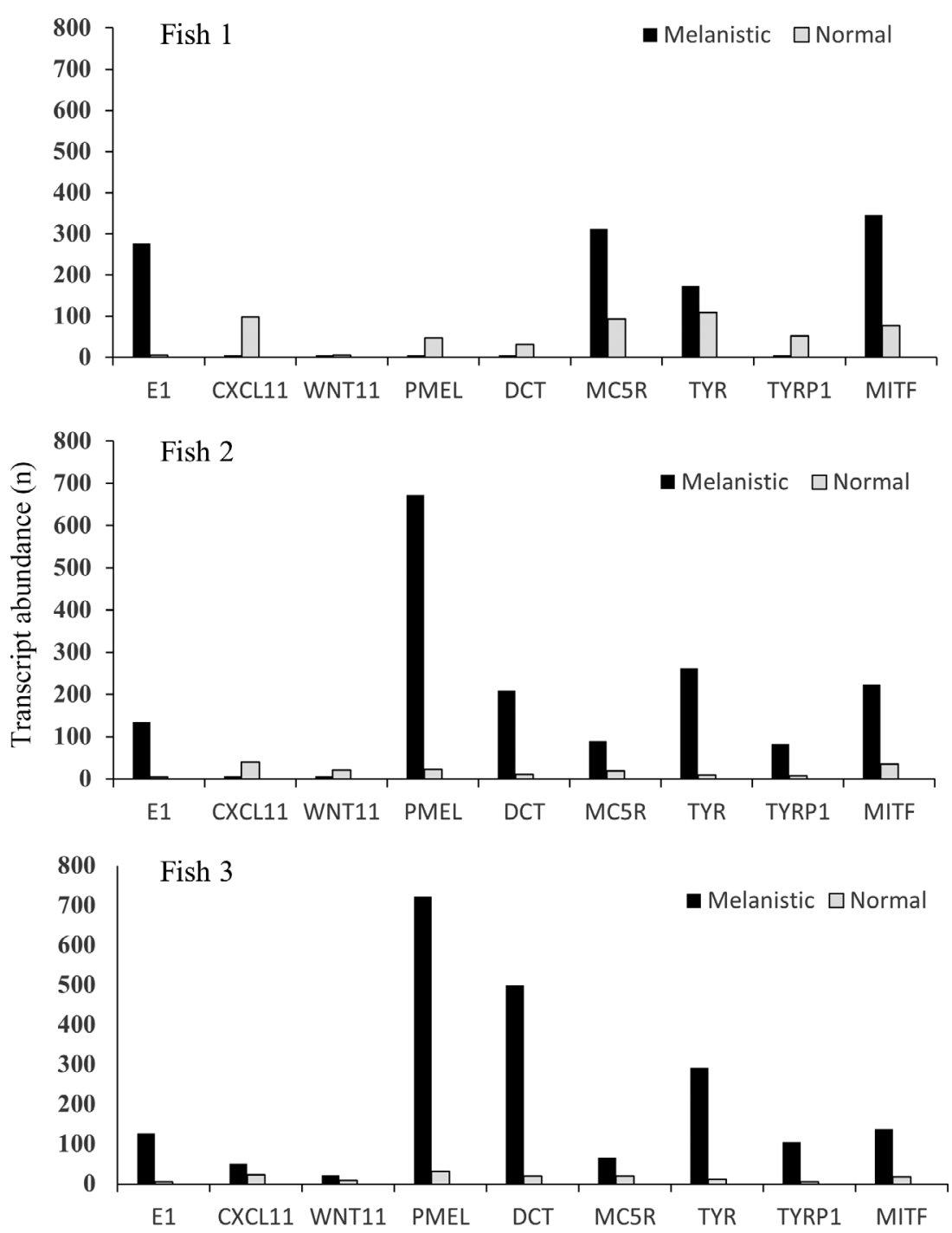

Fig. 6. Comparison of transcript abundance in melanistic and normal skin sections from 3 individual smallmouth bass. Fish 1 was collected in the West Branch Mahantango Creek, a tributary of the Susquehanna River in April 2017. Fish 2 and Fish 3 were collected in the mainstem Susquehanna River at Selinsgrove in November 2017. See Table 4 for full gene names
2005) were included in the transcript abundance analyses. Mitogen-activated kinase 1 (MAPK1), serine/threonineprotein kinase B-raf (BRAF), ras-related and estrogen-regulated inhibitor (RERG) and apoptosis-stimulating of p53 protein (TP53BP) were not found to be differentially expressed between normal and melanistic skin.

The transcript abundance analyses in this study did indicate that the HPMLs of smallmouth bass are associated with changes in melanocyte density and upregulation of melanin biogenesis. A premelanosome protein (PMEL) is necessary for melanosome structure formation and maturation (Jiang et al. 2014). In zebrafish, melanocyte stem cells give rise to $\mathrm{MITF}+$ melanoblasts which in turn give rise to the DCT+, TYR+, TYRP1+ differentiating or differentiated melanocytes/melanophores (Mort et al. 2015). Micropthalmia-associated transcription factor (MITF) is considered the master regulator of genes necessary for melanogenesis, cell growth, and survival. Melanogenesis involves sequential steps, the first and most rate limiting step being the oxidation of Ltyrosine by TYR to dopaquinone, while the next steps are catalyzed by DCT and TYRP-1 (Mason 1948, Riley 1997). Members of the Rab family, particularly Rab38, also play a key role in melanosome biogenesis (Coppola et al. 2016). Upregulation of DCT, TYR, TYRP-1, MC5R, MITF, PMEL, and Rab38 occurred in HPMLs when compared to normal skin of smallmouth bass.

The viral helicase (E1) initially identhese genes were differentially regulated in melanistic skin areas when compared to normal skin. Nor was there upregulation of cytochrome P450 enzymes (CYP1A, CYP2, and CYP3A) associated with exposure to contaminants such as polycyclic aromatic hydrocarbons and polycyclic chlorinated biphenyls, linked to hyperpigmentation in mammals, fish, and the African clawed frog Xenopus laevus (Kimura et al. 1984, Okihiro et al. 1993, Baumann \& Okihiro 2000, Fisher et al. 2003, Shimada \& Fujii-Kuriyama 2004, Gräns et al. 2015). A number of proto-oncogenes and tumor suppressor genes shown to be dysregulated in melanomas of zebrafish (Patton et al. tified, one of 8 early open reading frames (ORF) is the primary replication initiator protein for papilloma virus (Zheng \& Baker 2006). It is a protein essential for viral replication and was one of 3 unique sequences identified in HPMLs. The sequence is most similar (32.79\% identical) to the E01 helicase of the recently described guitarfish Rhynchobatus djiddensis adomavirus (Dill et al. 2018), belonging to a new viral family, the Adomaviridae (Welch et al. 2018). Similar to the current study, the conserved helicase domain was initially the only part of the adomavirus genome identified from guitarfish lesions by next generation sequencing and blast searches of avail- 
able databases. The infected guitarfish had both pigmented and nonpigmented villus-like skin lesions with nuclear inclusions containing viral particles which regressed over a 6 mo period (Camus et al. 2016).

There are a number of other observations that support a viral etiology for the smallmouth bass HPMLs. Transcript abundance analyses found E1 helicase transcripts to be below detection in all of the normal skin samples, yet present in most HPMLs (Table 5). Young et al. (2019) cohabitated affected and nonaffected individuals in tanks with ambient (11.3 to $\left.13.9^{\circ} \mathrm{C}\right)$ or heated $\left(20.3^{\circ} \mathrm{C}\right)$ spring water. Some fish which initially had HPMLs gained surface area (increased number and/or size of melanistic areas) at both ambient (46\%) and elevated (28\%) temperatures, while others lost surface area. Six of the 11 normalappearing bass developed HPMLs during the experiment, 3 at each temperature, suggesting an association with a transmittable agent. Transcript abundance analysis also showed upregulation of Akt1 in HPMLs. The Akt1 gene has pivotal roles in apoptosis, differentiation, and proliferation of cells (Dï-Poi et al. 2002). In mammals, Akt1 is part of the critical phosphatidylinositol 3-kinase (PI3K)/Akt/mammalian target of rapamycin (mTor) cascade pathway that is activated during a host response to viral infection (Diehl \& Schaal 2013). The PI3K/Akt/mTor cascade initiated by viral infection regulates autophagy of infected cells to degrade intracellular pathogens. In order for survival, viruses have evaded autophagy by increasing Akt regulation to prevent apoptosis. Studies have shown that the human papillomavirus is capable of activating Akt1 and consequently downregulate apoptotic proteins. This tactic causes hyperproliferation and inhibition of differentiation of infected cells, which in turn increases viral survival rate and time for replication to occur in keratinocytes (Charette \& McCance 2007, Surviladze et al. 2013).

Further sequence-based investigations are in progress to definitively identify and fully characterize the virus. Additional studies will be necessary to determine if the virus alone or in combination with certain environmental stressors is responsible for HPMLs of bass. Our results do not suggest there is an increasing prevalence of the melanistic lesions in the Susquehanna river watershed. Rather it appears that there is annual variation that could be associated with environmental factors. For instance, the overall prevalence in the Susquehanna mainstem during targeted sampling was $9 \%$ or above in 2012, 2014 and 2015 but $5 \%$ or less in 2013 and 2016. In the Juniata the prevalence was 3\% in 2015 but below $3 \%$ in all other years (Table 2). The Rockville site was sampled in all years from 2012 through 2017. Between 2013 and 2017 an overall decline was noted (Fig. 3). The prevalence of HPMLs on smallmouth bass also varied spatially. Routine population monitoring demonstrated the presence of affected bass at all sites in the Susquehanna and Juniata rivers at least once during the fall sampling from 2012-2017. In all years more melanistic bass were observed in the Susquehanna than in the Juniata (Table 2). A higher prevalence was also observed in the Susquehanna River watershed $(13 \%)$ when compared to sites from the Potomac River watershed (3\%) when all years/sites/seasons were combined from fish health monitoring data. Sites in the Potomac drainage all had a prevalence of $10 \%$ or less, while at some sites in the Susquehanna (i.e. Susquehanna at Selinsgrove, Susquehanna at Harrisburg, Juniata, Chillisquaque Creek and West Branch Mahantango Creek), 30\% or greater prevalence was noted at least once during the years sampled (Table 3). A caveat with the fish health monitoring data set is that only 20 fish per site/per sampling time were sampled, and many sites were only assessed once or twice between 2013 and 2018.

The current study did not specifically address seasonal or temperature effects. Data from the Rockville site would suggest an increase in HPMLs as the temperature decreases, with the exception of 2017 (Fig. 3). There was also no clear seasonal trend at 4 fish health monitoring sites sampled in both fall and spring 2016-2018. In the Potomac drainage when sampling occurred in both seasons more melanistic bass were observed in the fall. In the Susquehanna, Pine and West Branch Mahantango creeks more melanistic bass were collected in the spring in 2016 and 2017, but more in the fall in 2018. Further monitoring throughout the year, concurrently documenting water temperature and other parameters will be necessary to determine the role of temperature and other environmental stressors on this infection.

To our knowledge no previous studies have found an association between hyperpigmented areas in fish skin and viral pathogens, although pigmented lesions in humans have been associated with human papilloma virus (Egawa et al. 1998). Raised, papillmatous lesions, both pigmented and nonpigmented did contain viral particles in the epithelial cells of guitarfish (Camus et al. 2016). There is increasing evidence for the role of melanocytes in response to infectious diseases and tissue damage in mammalian (Gasque \& Jaffa-Bandjee 2015) and piscine (Lévesque et al. 2013) hosts. This disease offers a unique opportunity to better understand the role of melanocytes in disease resistance of fish and other organisms. Studies in ze- 
brafish found hyperpigmentation in response to tissue damage was due to recruitment of both melanoblasts and melanocytes to the area, and this recruitment depended on innate immune cells. Interestingly, in these studies, melanocytes varied in size, were pleomorphic and in some cases clustered around and surrounded implanted beads (Lévesque et al. 2013). In many HPMLs of smallmouth bass, pleomorphic epidermal melanocytes were often observed with dendritic projection around vacuolated and apoptotic cells.

In conclusion, the HPMLs of smallmouth bass may be associated with a new viral disease leading to the proliferation of melanocytes. Further studies will be necessary to (1) characterize the viral organism and definitely demonstrate its role in the melanistic lesions; (2) determine if the virus infects the melanocytes themselves or if the proliferation is a response to the presence of virus-infected cells; (3) understand the environmental influences associated with infection and (4) identify modes of transmission and infection. Development of image-based methods such as in situ hybridization will likely be necessary to identify infected cell types.

Acknowledgements. Funding for this project was provided by Pennsylvania Sea Grant, Pennsylvania Fish \& Boat Commission and the US Geological Survey's Environmental Health (Contaminant Biology) and Ecosystems (Environments and Fisheries) programs. Fish handling was conducted in accordance with the Leetown Science Center's Institutional Animal Care and Use guidelines. We thank Kathy Spring, Darlene Bowling and Pam Whittington for histological technical support and the many field biologists with Pennsylvania Fish and Boat Commission, Pennsylvania Department of Environmental Protection, Maryland Department of Natural Resources and West Virginia Division of Natural Resources who assisted with fish collections. Any use of trade, firm or product names is for descriptive purposes only and does not imply endorsement by the US Government.

\section{LITERATURE CITED}

Adachi K, Kato K, Wakamatsu K, Ito S and others (2005) The histological analysis, colorimetric evaluation, and chemical quantification of melanin content in 'suntanned' fish. Pigment Cell Res 18:465-468

Andersen CL, Ledet-Jensen J, Ørntoft T (2004) Normalization of real-time quantitative RT-PCR data: a modelbased variance estimation approach to identify genes suited for normalization applied to bladder- and coloncancer data-sets. Cancer Res 64:5245-5250

Arway JA, Smith G (2013) The Susquehanna River - a fishery in decline. Fisheries (Bethesda, MD) 38:235-236

Baumann P (1992) The use of tumors in wild populations of fish to assess ecosystem health. J Aquat Ecosyst Health 1: 135-146

Baumann PC, Okihiro MS (2000). Cancer. In: Ostrander GK (ed) The laboratory fish. Academic Press, San Diego, CA, p 591-616
Benjamini Y, Krieger AM, Yekutieli D (2006) Adaptive linear step-up procedures that control the false discovery rate. Biometrika 93:491-507

Blazer VS, Fournie JW, Wolf JC, Wolfe MJ (2007) Manual for the microscopic diagnosis of proliferative liver and skin lesions in the brown bullhead (Ameiurus nebulosus). U.S. Environmental Protection Agency, Washington, DC. EPA/600/R 12/036. https://cfpub.epa.gov (accessed 2 Feb 2019)

* Blazer VS, Iwanowicz LR, Starliper CE, Iwanowicz DD and others (2010) Mortality of centrarchid fishes in the Potomac drainage: survey results and overview of potential contributing factors. J Aquat Anim Health 22:190-218

Brocklebank JR, Armstrong RD (1994) Solar dermatitis in hatchery-reared salmonids in British Columbia. Can Vet J 35:651-652

* Camus A, Dill J, McDermott A, Camus M, Fan Ng TF (2016) Virus-associated papillomatous skin lesions in a giant guitarfish Rhynchobatus djiddensis: a case report. Dis Aquat Org 117:253-258

Carlson DM (1989) Unusual pigmentation on largemouth bass. Proc 45th Annual North East Fish and Wildlife Conference. Northeast Association of Fish and Wildlife Agencies, Ellenville, NY

Charette ST, McCance DJ (2007) The E7 protein from human papillomavirus type 16 enhances keratinocyte migration in an Akt-dependent manner. Oncogene 26:7386-7390

Coppola U, Annona G, D'Aniello S, Ristoratore F (2016) Rab32 and Rab38 genes in chordate pigmentation: an evolutionary perspective. BMC Evol Biol 16:26

E. Antiapoptotic role of PPAR $\beta$ in keratinocytes via transcriptional control of the Akt1 signaling pathway. Mol Cell 10:721-733

* Diehl N, Schaal H (2013) Make yourself at home: viral hijacking of the P13K/Akt signaling pathway. Viruses 5: 3192-3212

*Diggles BK, Ernst I, Wesche S (2018) Emergence of serranid pigment abnormality syndrome (SPAS) in wire netting cod (Epinephelus quoyanus) from Heron Island on the southern Great Barrier Reef. Mar Freshw Res 69:1201-1207

* Dill JA, Camus AC, Leary JH, Ng TFF (2018) Microscopic and molecular evidence of the first elasmobranch Adomavirus, the cause of skin disease in a giant guitarfish, Rhynchobatus djiddensis. MBio 9:e00185-18

* Egawa K, Honda Y, Inaba Y, Ono T (1998) Pigmented viral warts: a clinical and histopathological study including human papillomavirus typing. Br J Dermatol 138:381-389

Fisher MA, Jelaso AM, Predenkiewicz A, Schuster L, Means J, Ide CF (2003) Exposure to the polychlorinated biphenyl mixture Aroclor® 1254 alters melanocyte and tail muscle morphology in developing Xenopus laevis tadpoles. Environ Toxicol Chem 22:321-328

Gasque P, Jaffa-Bandjee MC (2015) The immunology and inflammatory responses of human melanocytes in infectious disease. J Infect 71:413-421

Gräns J, Wassmur B, Fernandez-Santoscoy M, Zanetter J, Woodin BR, Karchner SI (2015) Regulation of pregnane$\mathrm{X}$ receptor, CYP3A and P-glycoprotein genes in the $\mathrm{PCB}$ resistant killifish (Fundulus heteroclitus) population from New Bedford Harbor. Aquat Toxicol 159:198-207

G Gütjen F, Lang T, Feist S, Bruno D, Noguera P, Wosnick W (2013) Hyperpigmentation in North Sea dab Limanda limanda. I. Spatial and temporal patterns and host effects. Dis Aquat Org 103:9-24 
Jackson DA (2002) Ecological effects of Micropterus introductions: the dark side of black bass. Am Fish Soc Symp 31:221-232

Jiang Y, Zhang S, Xu J, Feng J, Mahboob S (2014) Comparative transcriptome analysis reveals the genetic basis of skin color variation in common carp. PLOS ONE 9:e108200

Kimura I, Taniguchi N, Kumai H, Tomita I and others (1984) Correlation of epizootiological observations with experimental data: chemical induction of chromatophoromas in the croaker, Niebea mitsukurii. Natl Cancer Inst Monogr 65:139-154

Kinae N, Yamashita M, Tomita I, Kimura I, Ishida H, Kumai H, Nakamura G (1990) A possible correlation between environmental chemicals and pigment cell neoplasia in fish. Sci Total Environ 94:143-153

Lang T, Feist SW, Stentiford GD, Bignell JP, Vethaak AD, Wosniok W (2017) Diseases of dab (Limanda limanda): analysis and assessment of data on externally visible diseases, macroscopic liver neoplasms and liver histopathology in the North Sea, Baltic Sea and off Iceland. Mar Environ Res 124:61-69

Lévesque M, Feng Y, Jones RA, Martin P (2013) Inflammation drives wound hyperpigmentation in zebrafish by recruiting pigment cells to sites of tissue damage. Dis Model Mech 6:508-515

Luna LG (1992) Histopathologic methods and color atlas of special stains and tissue artifacts. American Histolabs, Publications Division, Gaithersburg, MD

Kushchak VI (2011) Environmentally induced oxidative stress in aquatic animals. Aquat Toxicol 101:13-30

* Mason HS (1948) The chemistry of melanin: mechanism of the oxidation of dihydroxyphenylalanine by tyrosinase. J Biol Chem 172:83-99

Mort RL, Jackson IJ, Patton EE (2015) The melanocyte lineage in development and disease. Development 142:620-632

Noguera PA, Feist SW, Bateman KS, Lang T, Grütjen F, Bruno DW (2013) Hyperpigmentation in North Sea dab Limanda limanda. II. Macroscopic and microscopic characteristics and pathogen screening. Dis Aquat Org 103:25-34

Okihiro MS, Whipple JA, Groff JM, Hinton DE (1993) Chromatophoromas and chromatophore hyperplasia in Pacific rockfish (Sebastes spp.). Cancer Res 53:1761-1769

Otreba M, Wrzesniok D, Beberok A, Rok J, Buszman E (2014) Melanogenesis and antioxidant defense system in normal human melanocytes cultured in the presence of chlorpromazine. Toxicol In Vitro 29:221-227

* Patton EE, Widlund HR, Kutok JL, Kopani KR and others (2005) BRAF mutations are sufficient to promote nevi formation and cooperate with p53 in the genesis of melanoma. Curr Biol 15:249-254

Ramos P, Victor P, Branco S (2013) Spontaneous melanotic lesions in axillary seabream, Pagellus acarne (Risso). J Fish Dis 36:769-777

Riley PA (1997) Melanin. Int J Biochem Cell Biol 29:1235-1239

Rodriguez-Ariza A, Peinado J, Pueyo C, Lopez-Barea L (1993) Biochemical indicators of oxidative stress in fish from polluted littoral areas. Can J Fish Aquat Sci 50:2568-2580

Sanders RE, Miltner RJ, Yoder CO, Rankin ET (1999) The use of external deformities, erosion, lesions, and tumors, (DELT anomalies) in fish assemblages for characterizing aquatic resources: a case study of seven Ohio streams. In: Simon TP (ed) Assessing the sustainability and biological integrity of water resources using fish communities. CRC Press, Boca Raton, FL, p 225-246

Schartl M, Larue L, Goda M, Bosenberg MW, Hashimoto H, Kelsh RN (2016) What is a vertebrate pigment cell? Pigment Cell Melanoma Res 29:8-14
Shimada T, Fujii-Kuriyama Y (2004) Metabolic activation of polycyclic aromatic hydrocarbons to carcinogens by cytochrome P450 1A1 and 1B1. Cancer Sci 95:1-6

Shull D, Pulket M (2015) Causal analysis of the smallmouth bass decline in the Susquehanna and Juniata Rivers. Pennsylvania Department of Environmental Protection. http://files.dep.state.pa.us (accessed 12 May 2019)

Skinner KM, Pagels L, Peregrim KA (1994) Black blotch largemouth bass in the Hudson River, New York. In: Proc New York Natural History Conference III, April 13-16. American Museum of Natural History, New York, NY

Smith GM (1932) Eruptions of corial melanophores and general cutaneous melanosis in the goldfish (Carassius auratus) following exposure to X-ray. Am J Cancer 16:863-870

Smith GD, Blazer VS, Walsh HL, Iwanowicz LR, Starliper C, Sperry AJ (2015) The effects of disease-related mortality of young-of-year smallmouth bass on the population characteristics in the Susquehanna River basin, Pennsylvania and potential implications to conservation of black bass diversity. Am Fish Soc Symp 82:319-332

Stentiford GD, Bignell JP, Lyons BP, Feist SW (2009) Sitespecific disease profiles in fish and their use in environmental monitoring. Mar Ecol Prog Ser 381:1-15

* Stentiford GD, Bignell JP, Lyons BP, Thain JE, Feist SW (2010) Effect of age on liver pathology and other diseases in flatfish: implications for assessment of marine ecological health status. Mar Ecol Prog Ser 411:215-230

* Sugimoto M (2002) Morphological color changes in fish: regulation of pigment cell density and morphology. Microsc Res Tech 58:496-503

Surviladze Z, Sterk RT, DeHaro SA, Ozbun MA (2013) Cellular entry of human papillomavirus type 16 involves activation of the phosphatidylinositol 3-kinase/Akt/mTOR pathway and inhibition of autophagy. J Virol 87:2508-2517

* Sweet M, Kirkham N, Bendall M, Currey L, Bythell J, Heupel M (2012) Evidence of melanoma in wild marine fish populations. PLOS ONE 7:e41989

Vethaak AD, Jol JG, Pieters JPF (2009) Long-term trends in the prevalence of cancer and other diseases among flatfish in the southeastern North Sea as indicators of changing ecosystem health. Environ Sci Technol 43:2151-2158

* Walsh HL, Blazer VS, Smith GD, Lookenbill M, Alvarez DA, Smalling KL (2018) Risk factors associated with youngof-year smallmouth bass mortality in the Susquehanna River Basin, Pennsylvania, USA. J Aquat Anim Health 30:65-80

* Wang H, Zhai T, Wang C (2018) NanoStringDiff: differential expression analysis of NanoString nCounter Data. R package version 1.12.0. doi:10.18129/B9.bioc.NanoStringDiff

*Welch NL, Yunn N, Dill JA, Camus AC and others (2018) Adomaviruses: an emerging virus family provides insights into DNA virus evolution. bioRxiv doi:10.1101/341131

Work TM, Aeby GS (2014) Skin pathology in Hawaiian goldring surgeonfish Ctenochaetus strigosus (Bennett). J Fish Dis 37:357-362

Young KT (2018) Assessment of melanistic lesions in smallmouth bass (Micropterus dolomieu) of the Chesapeake Bay, USA. Graduate Theses, Dissertations and Problem Reports 7488. https://researchrepository.wvu. edu/etd/7488

Young K, Seiler S, Yamashita C, Davis S (2019) Surface area of 'blotchy bass' spots change over time in smallmouth bass (Micropterus dolomieu Lacepède, 1802). Keystone J Undergrad Res 6:1-6

K Zheng ZM, Baker CC (2006) Papillomavirus genome structure, expression, and post transcriptional regulation. Front Biosci 11:2286-2302

Submitted: October 30, 2019; Accepted: March 30, 2020

Proofs received from author(s): May 15, 2019 